\author{
Jurnal Penelitian Pos dan Informatika \\ 771/AU1/P2MI-LIPI/08/2017 \\ $32 a / E / K P T / 2017$ \\ e-ISSN 2476-9266 \\ p-ISSN: 2088-9402
}

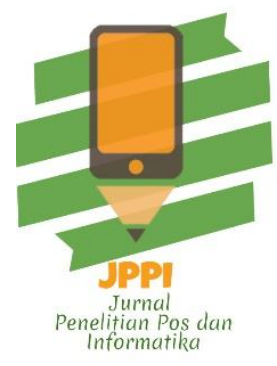

DOI:10.17933/jppi.2018.080102

\title{
PENGEMBANGAN APLIKASI UNTUK MERAMALKAN PENJUALAN BORDIR TASIKMALAYA MENGGUNAKAN METODE PENGHALUSAN EKSPONENSIAL
}

\section{DEVELOPMENT OF APPLICATION FOR FORECASTING TASIKMALAYA EMBROIDERY SALES USING EXPONENTIAL SMOOTHING METHOD}

\author{
Salman Alfarisi ${ }^{1}$, Lies Sunarmintyastuti ${ }^{2}$ \\ ${ }^{1,2}$ Program Studi Informatika - Universitas Indraprasta PGRI Jakarta \\ Jl. Jalan Nangka No.58 C, Tanjung Barat, Jagakarsa, Jakarta Selatan 12530 Indonesia \\ salman.hotaru@gmail.com
}

Naskah Diterima: 10 Oktober 2017; Direvisi : 29 Juli 2018; Disetujui : 29 Juli 2018

\begin{abstract}
Abstrak
Meramalkan produksi bordir untuk penjualan periode berikutnya merupakan hal yang selalu dilakukan oleh para produsen bordir Tasikmalaya. Biasanya para pengusaha bordir menggunakan intuisi diri sendiri berdasarkan data historis dan pengalaman mereka sendiri untuk menentukan jumlah produksi bordir mereka dan menulis sendiri di buku catatan penjualan bordir. Peramalan jumlah produksi merupakan salah satu kunci dalam keberhasilan penjualan karena dengan nilai peramalan penjualan bisa dijadikan acuan untuk menentukan suatu penjualan produk dimasa yang akan datang. Dalam menentukan nilai peramalan dalam sistem aplikasi ini menggunakan tiga metode penghalusan eksponensial yakni metode penghalusan eksponensial tunggal untuk menentukan peramalan bulan berikutnya, metode penghalusan eksponensial ganda dua parameter dari Holt untuk menentukan nilai peramalan berdasarkan trend, dan metode penghalusan eksponensial tiga kali untuk menentukan nilai peramalan berdasarkan musiman. Selain berisi tentang penghitungan nilai peramalan untuk di masa mendatang, sistem aplikasi ini juga digunakan sebagai media penyimpanan data hasil peramalan dan penjualan bordir serta dapat mencetak data hasil peramalan dan data penjualan.
\end{abstract}

Kata kunci: Sistem, Peramalan, Aplikasi

\section{Abstract}

Predicting the production of embroidery for the next period of sale is always done by Tasikmalaya embroidery manufacturers. Usually embroidery entrepreneurs use self-intuition based on their own historical data and experience to determine the amount of their embroidery production and write themselves in embroidery sales logbooks. Forecasting production amount is one of the key in sales success because with the value of sales forecasting can be used as a reference to determine a product sales in the future. In determining the forecasting value in this application system use three exponential smoothing methods ie single exponential smoothing method to determine next month forecasting, twoparameter double exponential smoothing method from Holt to determine forecasting value based on trend, and exponential smoothing method three times to determine forecast value based on seasonal. In addition to containing about the calculation of forecasting values for the future, this application system is also used as a data storage media forecasting and sale of embroidery and can print data forecasting and sales data.

Keywords: Systems, Forecasting, Applications 


\section{PENDAHULUAN}

Seiring dengan semakin berkembangnya teknologi di negara-negara yang berkembang termasuk Indonesia, maka diperlukan suatu sistem yang membantu proses distribusi barang secara efektif dan efesien, terutama dalam bidang komputerisasi. Perkembangan komputer dewasa ini terasa semakin kompleks, dimana kemajuan tersebut dapat dilihat dari telah banyak perusahaan berskala kecil hingga yang berskala besar diberbagai bidang yang menggunakan sistem terkomputerisasi untuk melaksanakan berbagai macam pekerjaan secara cepat dan dengan ketelitian yang tinggi.

Industri Bordir Tasikmalaya berkembang cukup pesat dan menyerap tenaga kerja yang cukup banyak ,khususnya kaum perempuan disekitar Kawalu maupun tenaga kerja dari berbagai daerah di kabupaten Tasikmalaya.. Daerah yang di kenal sebagai sentra Industri Bordir terdapat di Kecamatan Kawalu yaitu Desa Tanjung, Karsamenak, Cibeuti, Cilamajang, Talagasari, Gunung Tandala, Karang Anyar dan Karikil. Selanjutnya dengan adanya dukungan Pemerintah Kota Tasikmalaya, para pengusaha bordir mendapatkan lokasi di Pasar Tanah Abang Jakarta sebagai pusat penjualan Bordir Khas Tasikmalaya. Selain itu ada yang melaksanakan pemasarannya ke Thamrin City Jakarta, Pasar Baru Bandung, Pasar Tegal Gubug Cirebon, Pasar Turi Surabaya, Pasar Klewer Solo, Yogyakarta, Bali, Lombok, Manado, Ujung Pandang, Banjarmasin, Balikpapan, Medan, Riau, Pulau Batam, Makasar, Pontianak dan lainlain.
Permasalahan yang cukup besar adalah strategi apa yang akan digunakan dalam perencanaan dan peramalan jumlah permintaan konsumen untuk produk bordir, sehingga ada kepastian aktivitas produksi di masa yang akan datang. Dengan catatan kemampuan dan sumber daya perusahaan yang terbatas, namun dapat melayani konsumen lebih baik, melalui tersedianya hasil produksi yang jumlahnya lebih memadai seerta bermutu baik.

Untuk mengatasi masalah yang ada, maka dibutuhkan suatu rancang bangun aplikasi peramalan. Aplikasi peramalan ini dapat mempercepat perhitungan peramalan, sehingga hasil peramalan tersebut dapat membantu para produsen bordir salah satunya yang berlokasi di Tasikmalaya. Aplikasi peramalan tersebut digunakan untuk perkiraan penentuan jumlah produk yang harus diproduksi dengan tepat dan bermutu. Sistem yang dirancang bangun ini menggunakan bahasa pemrograman java sebagai aplikasi penyelesaian perhitungan peramalan untuk data produksi yang berdasarkan data penjualan untuk pola permintaan konsumen secara periodik,trend dan musiman.

Beberapa penelitian terdahulu yang pernah dilakukan berkaitan dengan perhitungan peramalan yaitu :

1. (Andini \& Auristandi, 2016), dengan judul Peramalan Jumlah Stok Alat Tulis Kantor di UD Achmad Jaya Menggunakan Metode Double Exponential Smoothing Kreasi). Dalam penelitian tersebut dihasilkan nilai peramalan dengan metode double exponential smoothing tetapi dalam bentuk perhitungan manual tanpa menggunakan aplikasi. 
2. Penelitian yang dilakukan oleh (Victor, Andreas, Prof, Suria, \& No, 2012) dengan judul Aplikasi Peramalan Stok Barang Menggunakan Metode Double Exponential Smoothing. Hasil penelitian ini adalah aplikasi peramalan dengan metode double exponential smoothing yang hanya dapat menghitung data yang memuat trend.

3. (Pramita \& Tanuwijaya, 2010) Dengan judul Penerapan Metode Exponential Smoothing Winter Dalam Sistem Informasi Pengendalian Persediaan Produk dan bahan Baku Sebuah Cafe. Dalam penelitian ini dihasilkan adalah aplikasi yang hanya menghitung nilai peramalan dengan metode penghalusan sebanyak 3 (tiga) kali atau triple exponential smoothing winter.

4. (Sabilla, 2014) Sabilla, Cantika Tara . Judul penelitiannya adalah Penerapan metode exponential smoothing untuk peramalan penggunaan waktu telepon di PT. Telkomsel Divre3 Surabaya. Hasil penelitian yang didapatkan adalah nilai peramalan untuk periode berikutnya tanpa menggunakan aplikasi untuk perhitungannya.

5. (Kristien Margi S., 2015). Dengan judul penelitian Analisa dan Penerapan Metode Single Exponential Smoothing Untuk Prediksi Penjualan Pada Periode Tertentu (Studi Kasus : PT. Media Cemara. Dalam penelitian ini dihasilkan nilai peramalan dengan menggunakan metode single exponential smoothing beserta aplikasinya.

Dari beberapa sumber literatur yang didapatkan, maka penelitian ini difokuskan dalam membuat aplikasi peramalan untuk penjualan bordir Tasikmalaya dengan menggunakan metode single exponential smoothing, double exponential smoothing dan triple exponential smoothing agar para pedagang bordir Tasikmalaya dapat memperkirakan jumlah produksi di bulan berikutnya, berdasarkan trend dan musiman sehingga membuat biaya produksi menjadi efisien dan pendapatan mereka menjadi lebih optimal.

\section{Peramalan}

Jay Heizer dan Barry Render (Render, 2015) menyatakan bahwa peramalan adalah suatu seni dan ilmu pengetahuan dalam memprediksi peristiwa-peristiwa pada masa mendatang. Peramalan akan melibatkan mengambil data historis (seperti penjualan tahun lalu) dan memproyeksikan mereka ke masa yang akan datang dengan model matematika. William J.Stevenson dan Sum Chee Chuong (Chuong, 2014) menyatakan bahwa peramalan (forecast) adalah pernyataan mengenai nilai yang akan datang dari variable seperti permintaan. Artinya ramalan adalah prediksi mengenai masa depan. Sedangkan (Assauri, 2016) menyatakan bahwa prakiraan ramalan adalah kegiatan memprediksi nilai masa depan, dengan dasar pengetahuan atau nilai masa lalu yang dipersiapkan. Prakiraan ramaln mencakup penggunaan data historis, dengan memproyeksikannya untuk masa depan yang menggunakan jenis model matematis.. Berdasarkan beberapa definisi diatas ,pada hakikatnya peramalan merupakan suatu keputusan tentang kemungkinan masa yang akan datang yang didasarkan fakta-fakta ekonomi sekarang dan sejarah masa lalu. Sebelum melakukan peramalan harus diketahui lebih dulu persoalan dalam pengambilan keputusan. Dengan 
adanya peramalan manajemen dapat segera menyiapkan langkah paling baik dalam mengatasi permasalahan dan dapat bersiap-siap memanfaatkan situasi jika terjadi perkembangan yang lebih baik dalam peramalan. Peramalan yang menjadi titik tolak bagi tindakan perusahaan adalah ramalan penjualan. Pengertian ramalan penjualan adalah proyeksi teknis permintaan konsumen yang potensial pada masa yang akan datang dengan menggunakan berbagai pendekatan. Hal ini sangat berhubungan dengan kegiatan produksi. Dalam proses produksi kegiatan yang dilaksanakan dalam peramalan adalah untuk menentukan jumlah permintaan konsumen terhadap suatu produk yang dilakukan pada awal proses perencanaan dan untuk kepentingan proses pengendalian produksi. Oleh sebab itu perangkat lunak sangat dibutuhkan, untuk mendukung peramalan permintaan konsumen untuk mempercepat, mempermudah dan menghindari hitungan dengan tangan yang kemungkinan terjadi kesalahan.

Data deret berkala (time series) merupakan data yang dikumpulkan, dicatat atau diobsevasi sepanjang waktu secara berurutan. Periode waktu observasi dapat berbentuk tahun, kuartal, bulan, minggu dan dibeberapa kasus dapat juga hari atau jam. Time series dianalisis untuk menemukan pola variasi masa lalu yang dapat dipergunakan untuk memperkirakan nilai masa depan dan membantu dalam manajemen operasi serta membuat perencanaan.

Analisis deret berkala dapat dilakukan dengan mengamati data dan melihat apakah empat komponen data deret berkala yang mempengaruhi suatu pola data masa lalu dan sekarang, yang cenderung berulang di masa mendatang terdapat di data tersebut. Empat komponen pola deret waktu, antara lain :

1. Trend, yaitu pergerakan data secara bertahap keatas atau kebawah secara bertahun-tahun.

2. Musiman, yaitu pola data yang mengulang dengan sendirinya setelah satu periode (hari, minggu, bulan, atau kuartalan) dan berfluktuasi secara musiman

3. Siklus, yaitu pola data yang terjadi setiap beberapa tahun. Siklus dari data data deret berkala akibat dari kondisi ekonomi atau peristiwa politik dan hal ini sangat penting dalam analisis jangka pendek.

4. Variasi secara acak, yaitu pola acak didalam data yang disebabkan oleh adanya peristiwa yang tidak bisa diprediksi atau tidak beraturan

\section{Peramalan Metode Exponential Smothing}

\section{Metode Single Exponential Smoothing}

Metode ini memberikan bobot berdasarkan level ( $\alpha$ ), Bentuk matematis dari metode Single Exponential Smoothing ditunjukan

$$
F_{t}=\alpha A_{t-1}+(1-\alpha) F_{t-1}
$$

sebagai berikut:

Dimana :

$$
\begin{aligned}
\mathrm{F}_{\mathrm{t}} & =\text { Ramalan Baru } \\
\mathrm{F}_{\mathrm{t}-1} & =\text { Ramalan Sebelumnya } \\
\alpha & =\text { Konstanta Penghalusan } \\
\mathrm{A}_{\mathrm{t}-1} & =\text { Permintaan aktual periode }
\end{aligned}
$$

Sebelumnya

2. Metode Double Exponential Smoothing (Metode Holt)

Metode ini merupakan pengembangan dari Single Exponential dimana menambahkan unsur trend pada bobot perhitungan, sehingga pada Double Exponential Smoothing (Metode 
Holt) kita memberikan dua jenis bobot pada perhitungan yaitu level $(\alpha)$ dan trend $(\beta)$. Bentuk matematis dari Double Exponential Smoothing ditunjukan sebagai berikut :

$$
\begin{aligned}
& A_{t}=\alpha Y_{t}+(1-\alpha)\left(A_{t-1}+T_{t-1}\right) \\
& T_{t}=\beta\left(A_{t}-A_{t-1}\right)+(1-\beta) T_{t-1} \\
& F_{t+m}=A_{t}+T_{t} m
\end{aligned}
$$

Dimana :

$$
\begin{aligned}
& \text { At }=\text { nilai pemulusan eksponensial } \\
& \alpha=\text { konstanta pemulusan untuk data } \\
& (0<\alpha<1) \\
& \beta=\text { konstanta pemulusan untuk estimasi } \\
& \text { trend }(0 \leq \beta \leq 1) \\
& \mathrm{Y}_{\mathrm{t}}=\text { nilai aktual pada periode } \mathrm{t} \\
& \mathrm{T}_{\mathrm{t}}=\text { estimasi trend, } \\
& \mathrm{F}(\mathrm{t}+\mathrm{m})=\text { Nilai ramalan. }
\end{aligned}
$$

\section{Metode Triple Exponential Smoothing}

Metode Triple Exponential Smoothing atau dapat dikenal dengan nama "Winter's Method“, merupakan pengembangan dari Double Exponential dimana melakukan peramalan dengan tiga parameter dengan bobot yang berbeda yaitu level $(\alpha)$, trend $(\beta)$ dan seasonal $(\gamma)$. Berdasarkan tipe musiman (Triple Exponential Smoothing) dibagi menjadi dua yaitu:

\section{a. Multiplicative Seasonal Model}

\section{b. Additive Seasonal Model}

Perbedaan keduanya adalah Pada Multiplicative Seasonal Model yaitu mengalikan hasil perhitungan level dan trend dengan perhitungan Seasonal. Sedangkan Additive Seasonal Model yaitu menambahkan hasil perhitungan level dan trend dengan perhitungan Seasonal. Tetapi yang akan di bahas disini hanya Triple Exponential
Smoothing dengan Multiplicative Seasonal Model. Bentuk matematis dari perhitungannya adalah sebagai berikut :

$$
\begin{aligned}
& A_{t}=\alpha \frac{Y_{t}}{S_{t-L}}+(1-\alpha)\left(A_{t-1}+T_{t-1}\right) \\
& T_{t}=\beta\left(A_{t}-A_{t-1}\right)+(1-\beta) T_{t-1} \\
& S_{t}=\mu \frac{Y_{t}}{A_{t}}+(1-\mu) S_{t-L} \\
& \hat{Y}_{t+p}=\left(A_{t}+T_{t} p\right) S_{t-L+p}
\end{aligned}
$$

Dimana :

$A_{t}=$ nilai pemulusan eksponensial

$\alpha=$ konstanta pemulusan untuk data

$(0 \leq \alpha \leq 1)$

$\beta=$ konstanta pemulusan untuk estimasi trend $(0 \leq \beta \leq 1)$

$\mu=$ konstanta pemulusan untuk estimasi musiman $(0 \leq \mu \leq 1)$,

$\mathrm{Y}_{\mathrm{t}}=$ nilai aktual pada periode $\mathrm{t}$

$\mathrm{T}_{\mathrm{t}}=$ estimasi trend

$\mathrm{S}_{\mathrm{t}}=$ estimasi musiman

$\mathrm{L}=$ panjangnya musim

$\mathrm{p}=$ jumlah periode ke depan yang akan diramalkan

\section{Mengukur Kesalahan Peramalan}

Beberapa ukuran yang digunakan dalam praktiknya untuk menghitung keseluruhan dalam kesalahan peramalan. Ukuran-ukuran ini dapat digunakan untuk membandingkan model peramalan yang berbeda, sejalan dengan untuk memonitor peramalan untuk memastikan bahwa mereka berfungsi dengan baik. Tiga ukuran yang paling terkenal adalah deviasi rata-rata yang absolut (mean absolute deviation--MAD), kesalahan rata-rata-rata yang dikuadratkan (mean squared error--MSE), dan kesalahan persentase rata-rata yang absolut (mean 
absolute percent error--MAPE). Tetapi disini akan ditambahkan kesalahan rata-rata (mean error--ME) sebagai acuan pertama mencari nilai error.

1. ME (Mean Error) atau Nilai Rata-Rata Kesalahan

$\mathrm{ME}=\frac{\text { EAktwal }- \text { Peramalan }}{\mathrm{n}}$

2. MAD (Mean Absolute Deviation) atau Nilai Deviasi Rata-Rata Kesalahan Absolute

$$
\mathrm{MAD}=\frac{\sum \llbracket \text { Aktual }- \text { Peramalan } \|}{\mathrm{n}}
$$

3. MSE (Mean Square Error) atau Nilai Rata-Rata Kesalahan Kuadrat

MSE $=\frac{\sum \text { [Aktwal }- \text { Peramalan }^{2}}{\mathrm{n}}$

4. MAPE (Mean Absolute Percent Error) atau Nilai Rata-Rata Kesalahan Persentase Absolute MAPE $=\frac{\sum_{i-1}^{n} 100 \mid A k t w a l_{i}-A k t w a l_{i} \| / A k t w a l_{i}}{n}$

\section{METODE}

\section{Jenis Penelitian}

Penelitian ini melibatkan data, perhitungan dan penarikan kesimpulan. Data tersebut diambil dari data historis dan kuesioner. Sedangkan penghitungan teknik peramalan dengan Single Exponential Smoothing Model dan Double Exponential Smoothing Model serta Triple Exponential Smoothing dengan Multiplicative Seasonal Model menggunakan teknik statistika. Metode yang digunakan untuk pengembangan sistem adalah metode waterfall (Komunikasi, Perencanaan, Pemodelan, Konstruksi dan Pemeliharaan sistem) sedangkan pembuatan perangkat lunak tersebut menggunakan bahasa pemrograman Java dengan database menggunakan MySQL.

\section{Populasi dan Sampel}

Populasi dalam penelitian ini adalah produsen bordir Tasikmalaya yang berjualan di Pasar Tanah Abang Jakarta yang berjumlah kurang lebih 150 pedagang . Dalam pemilihan dan penentuan sampel adalah secara acak (random sampling) secara individual. Disamping itu menggunakan responden tenaga ahli yang diambil dari pembina/ Ketua koperasi dan tenaga ahli dari produsen bordir.

\section{Metode Pengumpulan Data}

Metode pengumpulan data yang digunakan dalam penelitian ini adalah Riset kepustakaan (Library Research) dan Riset Lapangan (Field research). Penelitian kepustakaan dilakukan untuk mendapatkan data sekunder maupun teori-teori yang berhubungan dengan penelitian. Peneliti mengadakan peninjauan langsung ke lokasi responden ditempat produksi maupun di tempat berjualannya, sehingga diperoleh gambaran tentang masalah yang menjadi objek penelitian. Cara yang digunakan peneliti adalah dengan menyebarkan angket kepada responden, dimana responden diminta untuk mengisi angket yang telah disediakan oleh peneliti. Responden dalam penelitian ini adalah produsen pengusaha bordir Tasikmalaya yang berjualan di lokasi Pasar Tanah Abang Jakarta.

\section{Teknik Pengolahan dan Analisis Data}

Pengolahan dan Analisa Data Historis menggunakan teknik : Single Exponential Smoothing Model, Double Exponential Smoothing Model, Triple Exponential Smoothing dengan Multiplicative Seasonal Model dengan perhitungan manual menggunakan Microsoft Excel, selanjutnya pengolahan dan analisis perangkat lunak menggunakan bagan alir data 
berbentuk flowchart, untuk pengembangan perangkat lunak menggunakan metode waterfall, pengkodean menggunakan bahasa pemrograman Java serta untuk database menggunakan MySQL.

\section{HASIL DAN PEMBAHASAN}

\section{Deskripsi Data}

Data yang diperlukan dalam penelitian ini diperoleh melalui instrument kuesioner yang berisi data historis penjualan perbulan selama 3 tahun (2015, 2014 dan 2013) dari responden dan data dari hasil wawancara kepada produsen sekaligus pedagang, dimana datanya adalah sebagai berikut :

Tabel 1 Data Penjualan Bordir Tasikmalaya Toko A Jan 2013 s/d Des 2015

\begin{tabular}{|c|r|}
\hline month & actual \\
\hline Jan-13 & 105 \\
\hline Feb-13 & 115 \\
\hline Mar-13 & 130 \\
\hline Apr-13 & 130 \\
\hline May-13 & 120 \\
\hline Jun-13 & 130 \\
\hline Jul-13 & 140 \\
\hline Aug-13 & 115 \\
\hline Sep-13 & 125 \\
\hline Dot-13 & 120 \\
\hline Nou-13 & 130 \\
\hline Dec-13 & 140 \\
\hline Jan-14 & 145 \\
\hline Feb-14 & 155 \\
\hline Mar-14 & 170 \\
\hline Apr-14 & 170 \\
\hline May-14 & 160 \\
\hline Jun-14 & 175 \\
\hline Jul-14 & 190 \\
\hline Aug-14 & 150 \\
\hline Sep-14 & 165 \\
\hline Dot-14 & 160 \\
\hline Nou-14 & 170 \\
\hline Deo-14 & 190 \\
\hline Jan-15 & 220 \\
\hline Feb-15 & 235 \\
\hline Mar-15 & 245 \\
\hline Apr-15 & 240 \\
\hline May-15 & 245 \\
\hline Jun-15 & 270 \\
\hline Jul-15 & 280 \\
\hline Aug-15 & 250 \\
\hline Sep-15 & 250 \\
\hline Dot-15 & 240 \\
\hline Nou-15 & 250 \\
\hline Deo-15 & 275 \\
\hline Meo & \\
\hline
\end{tabular}

Dari data diatas akan disajikan dengan grafik agar bisa dilakukan analisis sehingga terlihat bahwa data tersebut termasuk kedalam jenis pola data deret berkala.

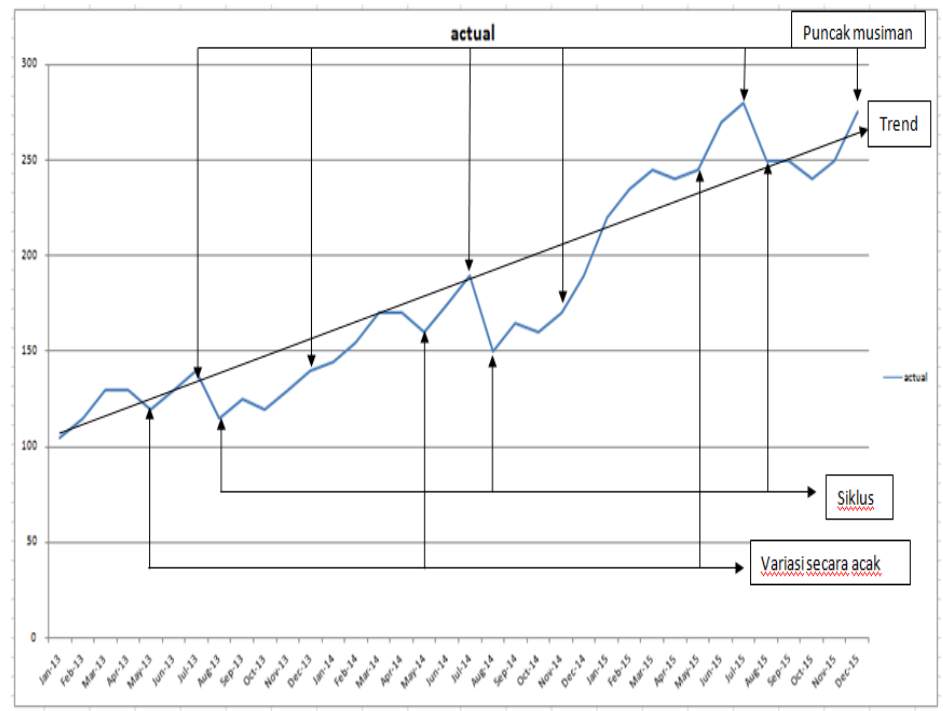

. Gambar 1 Hasil Analisis Data Deret Berkala

Berikut adalah penjelasan grafik diatas :

1. Kecenderungan (trend) adalah pergerakan data secara bertahap keatas atau kebawah secara bertahun-tahun. Pada data yang kami peroleh dari pedagang selama 3 (tiga) tahun (2013, 2014, 2015), menunjukkan peningkatan yang terus-menerus. Analisis bisnis ini sangat penting untuk jangka panjang yang mendasari pertumbuhan atau penurunan suatu data time series.

2. Musiman adalah pola data yang mengulang dengan sendirinya setelah satu periode (hari, minggu, bulan, atau kuartalan) dan berfluktuasi secara musiman. Pada data diatas (tahun 2013,2014 dan 2015 ), menunjukkan bahwa puncak musiman terjadi pada bulan juni (liburan sekolah), juli (lebaran), desember (liburan sekolah).

3. Siklus adalah pola data yang terjadi setiap beberapa tahun. Fluktuasi atau siklus dari data time series akibat dari kondisi ekonomi atau peristiwa politik dan hal ini sangat penting dalam analisis jangka pendek. Pada pola data 
diatas selama 3 (tiga) tahun setiap bulan agustus, menunjukkan penurunan daya beli (grafik turun secara drastis). Hal ini disebabkan karena adanya tradisi mudik di Indonesia, sehingga terjadi penurunan penjualan.

4. Variasi secara acak (tak beraturan) adalah pola acak didalam data yang disebabkan oleh adanya peristiwa yang tidak bisa diprediksi atau tidak beraturan. Dari grafik pola data diatas, selama 3 (tiga tahun) menunjukkan secara berturut-turut selama 2 (dua) tahun (2013 dan 2014) setiap bulan mei pola data penjualan naik, tetapi pada bulan mei tahun 2015 pola data penjualan menurun.

Dari penjelasan diatas, maka dapat disimpulkan bahwa data yang diperoleh menunjukkan data time series, karena telah memenuhi 4 (empat) komponen pola data yang bisa di analisis dengan model time series yaitu : kecenderungan (trend), musiman, siklus, dan variasi secara acak. Selanjutnya data akan diolah dengan 3 model pemulusan (single, double dan triple exponential smoothing) menggunakan sistem peramalan yang dibuat dengan editor NetBeans berbahasa pemrograman Java dan basis data menggunakan MySQL berdasarkan rancangan sistem yang dibuat dengan flowchart.

\section{Flowchart Sistem}

Bagan Alir (flowchart) digunakan untuk alat bantu komunikasi dan untuk dokumentasi (Pressman, 2010) Flowchart untuk sistem ini dibagi menjadi 3 flowchart untuk masing-masing peramalan (single exponential smoothing, double exponential smoothing dan triple exponential smoothing), tetapi pada penelitian ini flowchart yang diberikan hanya flowchart untuk peramalan double exponential smoothing.

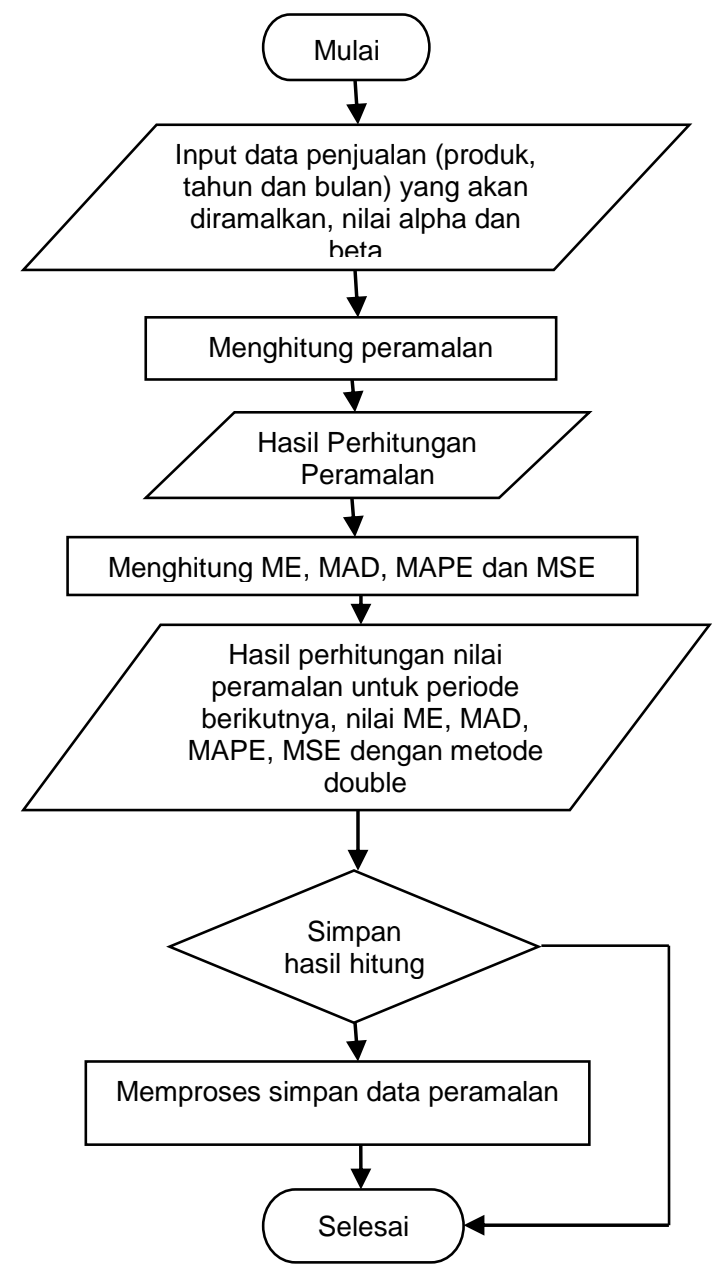

Gambar 2 Flowchart sistem peramalan dengan perhitungan double exponential smoothing

Bagan alir program perhitungan di atas dapat dijelaskan sebagai berikut :

1. Memasukkan data penjualan yang akan diramalkan serta nilai alpha dan beta

2. Menghitung nilai peramalan.

3. Hasil perhitungan peramalan

4. Menghitung nilai Mean Error (ME), nilai Mean Absolute Deviation (MAD), nilai Mean Percentage Error (MAPE), dan nilai Mean Square Error (MSE)

5. Keluaran untuk ramalan periode berikutnya serta nilai ME, MAD, MAPE, MSE dengan metode double exponential smoothing.

6. Jika ingin menyimpan hasil peramalan maka 
komputer akan memproses penyimpanan data

kemudian selesai. Jika tidak maka selesai.

\section{Pseudocode}

Menurut (Rachmat, 2010), "Pseudocode berasal dari kata pseudo dan code, yang artinya kode semu, atau menyerupai kode sebenarnya". Pseudocode berbasis Bahasa pemrograman seperti Pascal, C++ atau Borland Delphi, dan lebih tepat digunakan untuk menggambarkan algoritma yang akan dikomunikasikan kepada programmer.

Pseudocode untuk perhitungan double exponential smoothing adalah sebagai berikut :

Tampilan tab perhitungan peramalan Double

Pilih combo box kode aktual

Input nilai alpha dan beta

Pilih button hitung

Proses hitung nilai peramalan double dan semua nilai error

Output nilai ramalan periode berikutnya serta nilai ME, MAD, MAPE, MSE dengan metode double exponential smoothing.

Pilih button simpan

\section{Aplikasi Sistem Peramalan}

Aplikasi sistem peramalan memiliki kemampuan untuk menyimpan data penjualan dan peramalan, menghitung peramalan dengan tiga metode (single exponential smoothing, double exponential smoothinge, dan triple exponential smoothing dengan multiplicative seasonal model) serta membuat laporan hasil peramalan kepada tiap-tiap pengusaha bordir dengan mudah dan akurat sesuai dengan kebutuhan dari para pengusaha bordir.

Secara umum aplikasi ini terbagi dalam beberapa menu yaitu :

1. Halaman Login, digunakan sebagai menu awal ketika user ingin masuk kedalam sistem.
Hal ini untuk menjaga agar sistem ini hanya bisa diakses oleh orang-orang yang berhak saja, yaitu user.

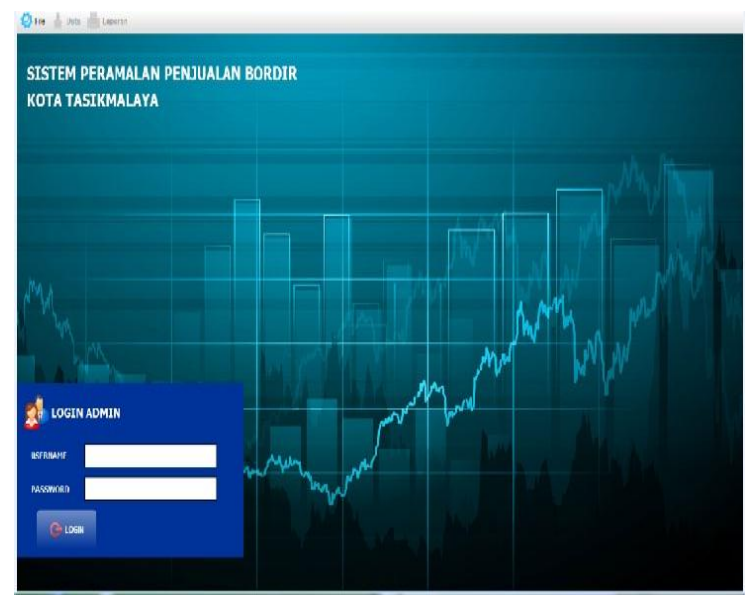

Gambar 3 Halaman awal (Login) sistem peramalan

2. Penginputan data aktual, digunakan untuk memasukkan data barang berdasarkan kode barang, nama barang, bulan dan jumlah penjualan barang (nilai aktual) penjualan bordir. Dalam menu tersebut ada tombol pilihan yaitu tambah (digunakan untuk memasukkan data), edit (untuk mengubah data jika ada kesalahan ), hapus ( untuk menghapus data jika datanya salah), dan exit (untuk keluar dari halaman input data aktual).

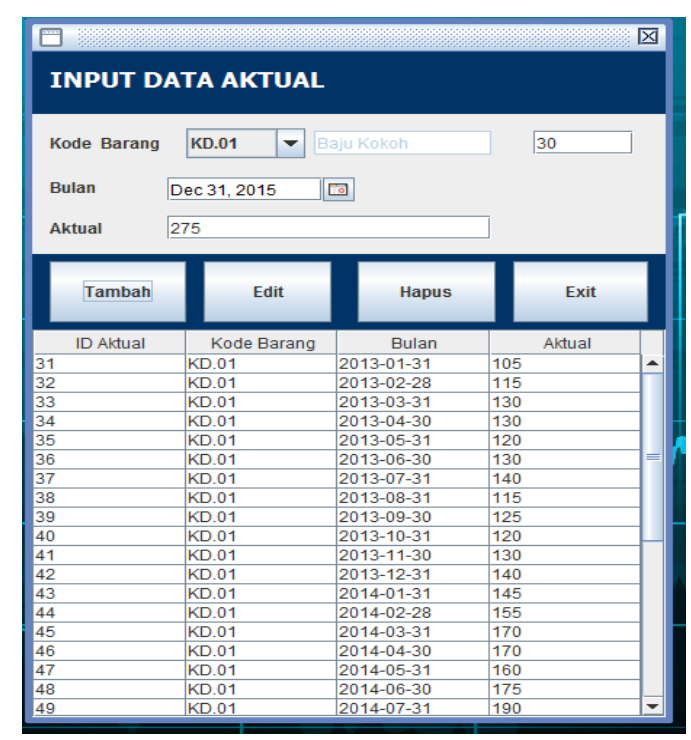

Gambar 4 Form input data aktual 
3. Menu data ramalan terdiri dari 3 (tab) yakni tab single, double dan triple. Tab single digunakan untuk perhitungan nilai peramalan dengan cara memasukkan kode aktual yang sesuai dengan kode barang yang akan dihitung nilai peramalannya, setelah itu masukkan nilai alpha antara nilai 0.1 sampai 0.9, kemudian tekan tombol hitung dan akan keluar hasil dari peramalan dengan metode single exponential smoothing. Tombol simpan berfungsi untuk menyimpan hasil perhitungan peramalan ke database.

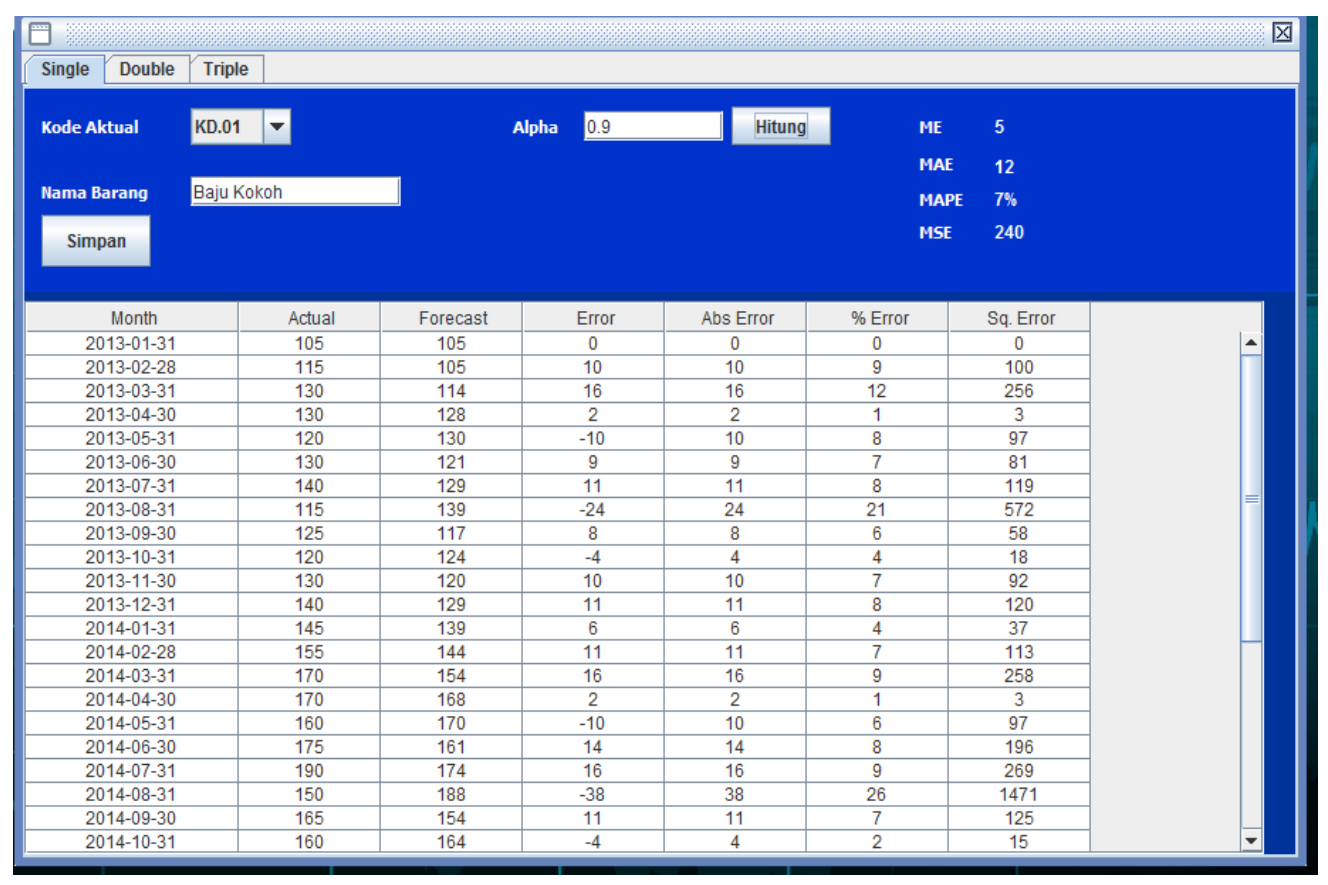

Gambar 5 Form perhitungan nilai peramalan single exponential smoothing

Berdasarkan hasil perhitungan dari Single Exponential Smoothing Model dengan menggunakan nilai $\alpha=0.1,0.5$ dan 0.9 ,maka didapat nilai error terkecil dengan menggunakan 4 (empat) metode yang memperoleh hasil $\mathrm{ME}=5$, $\mathrm{MAD}=12, \mathrm{MAPE}=7 \%$ dan $\mathrm{MSE}=240$,yaitu dari nilai $\alpha=0.9$. Nilai $\alpha$ inilah yang akan digunakan untuk menghitung nilai peramalan pada periode berikutnya. Single Exponential Smoothing Model digunakan pada peramalan jangka pendek, biasanya satu bulan kedepan. Model ini mengasumsikan bahwa data berfluktuasi disekitar nilai mean yang tetap ,tanpa trend atau pola pertumbuhan. Hal ini juga didukung oleh penelitian yang relevan sebelumnya oleh Kristen Margi S dan Sofian Pendawa W yang mengatakan bahwa tingkat error yang terkecil (hasil dari MSE dan MAPE terkecil) yang akan dijadikan sebagai acuan penjualan pada periode berikutnya. Hal ini juga sesuai pendapat yang diungkapkan oleh William J Stevenson dan Sum Chee Chuong (2014) yang menyebutkan bahwa kecepatan penyesuaian ramalan terhadap kesalahan ditentukan dengan konstanta pemulusan $\alpha$. Semakin dekat nilai $\alpha$ dengan nol, semakin lambat ramalan akan menyesuaikan diri dengan kesalahan ramalan. Sebaliknya semakin dekat nilai $\alpha$ dengan 1,00 semakin besar kemampuan untuk merespon dan pemulusan lebih kecil.

Tab double digunakan digunakan untuk perhitungan nilai peramalan dengan cara memasukkan kode aktual yang sesuai dengan 
kode barang yang akan dihitung nilai tekan tombol hitung dan akan keluar hasil dari peramalannya, setelah itu masukkan nilai alpha peramalan dengan metode double exponential dan beta antara nilai 0.1 sampai 0.9 , kemudian smoothing.

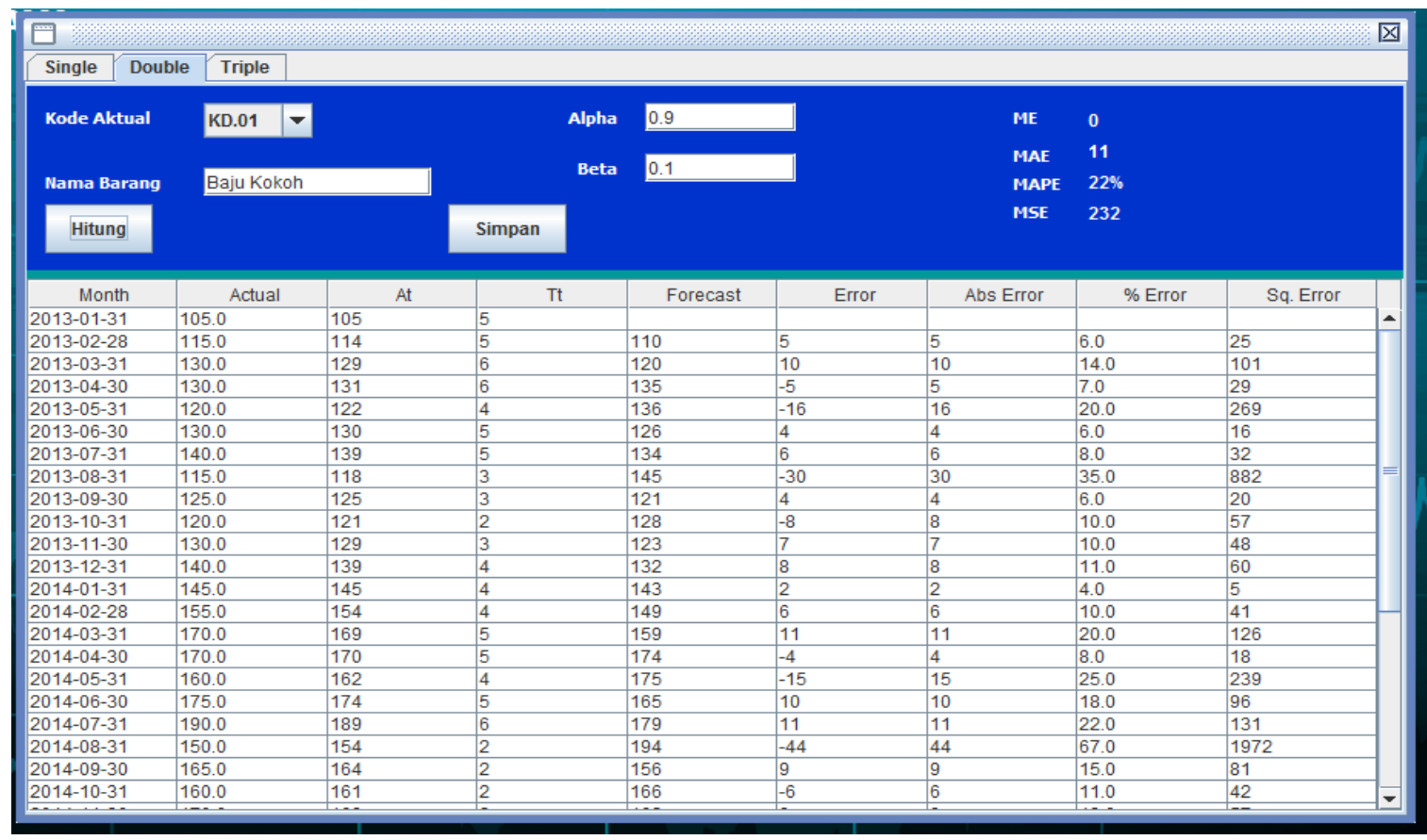

Gambar 6 Form perhitungan nilai peramalan double exponential smoothing

Perhitungan Double Exponential Smoothing Model yang dilakukan dengan menggunakan kombinasi nilai $\alpha=0,1,0,5,0,9$ dan nilai $\beta=0,1$ ,0,5, 0,9. Dari hasil perhitungan didapat hasil nilai error yang terkecil yaitu : $\mathrm{ME}=0, \mathrm{MAD}=$ $11, \mathrm{MAPE}=22 \%, \mathrm{MSE}=232$ yang diperoleh dari kombinasi nilai $\alpha=0,9$ dan nilai $\beta=0,1$. Model Double Exponential Smoothing mempunyai kinerja yang bagus dalam meramalkan data dengan nilai perhitungan tingkat error yang paling kecil terhadap data pengamatan sebenarnya di lapangan. Hal tersebut juga didukung oleh penelitian sebelumnya oleh Titani Dwi Andini dan Probo Auristandi ( 2016 ) dengan judul Peramalan Jumlah Stock Alat Tulis Kantor di UD Achmad Jaya Menggunakan Metode Doble Exponential Smoothing, yang menyatakan.bahwa
MAPE terkecil akan digunakan sebagai peramalan untuk periode berikutnya. Untuk menghasilkan akurasi yang tinggi dalam metode peramalan Double Exponential Smoothing sebaiknya memperhatikan pola data dengan baik, karena Double Exponential Smoothing untuk pola data mengandung trend.

Tab triple digunakan digunakan untuk perhitungan nilai peramalan dengan cara memasukkan kode aktual yang sesuai dengan kode barang yang akan dihitung nilai peramalannya, setelah itu masukkan nilai alpha dan beta serta gamma antara nilai 0.1 sampai 0.9 , kemudian tekan tombol hitung dan akan keluar hasil dari peramalan dengan metode triple exponential smoothing. 


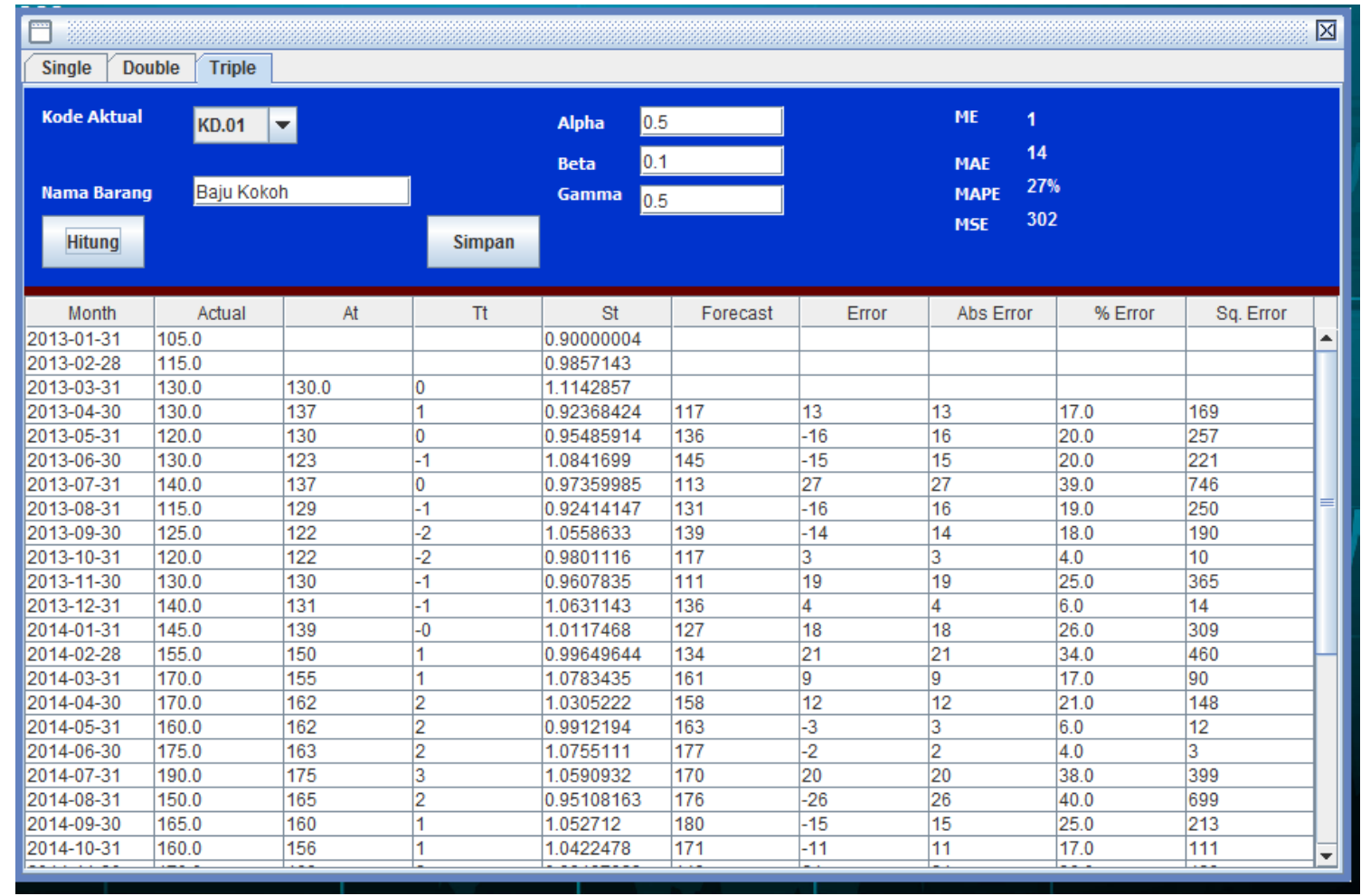

Gambar 7 Form perhitungan nilai peramalan triple exponential smoothing

Perhitungan Model Triple Exponential Selain itu juga sejalan dengan penelitian terdahulu Smoothing dengan Multiplicative Seasonal Model oleh Noeryanti ,Ely Oktaviani ,Fera Andriyani dengan menggunakan kombinasi $\alpha=0,1,0,5,0,9$ (2012) dengan judul Aplikasi Pemulusan dan $\beta=0,1,0,5,0,9$ serta $\gamma=0,1,0,5,0,9$. Hasil Exponential Dari Holt Untuk Data yang Memuat perhitungan didapatkan error terkecil yaitu $\mathrm{ME}=$ $1, \mathrm{MAD}=14, \mathrm{MAPE}=27 \%$ dan MSE $=302$ dari kombinasi $\alpha=0,5, \beta=0,1$ dan $\gamma=0,5$. Metode Triple Exponential Smoothing dengan Multiplicative Seasonal Model menyatakan bahwa dari hasil perbandingan peramalan tersebut yang memiliki error yang terkecil akan digunakan sebagai informasi prediksi penjualan produk untuk periode berikutnya. Hal ini juga didukung oleh penelitian terdahulu oleh Wahyu Pramita, Haryanto Tanuwijaya ( 2010 ) dengan judul Penerapan Metode Exponential Smoothing Winter Dalam Sistem Informasi Pengendalian Persediaan Produk dan Bahan Baku Sebuah Cafe menjelaskan bahwa dengan menggunakan nilai MSE terkecil digunakan untuk prediksi periode berikutnya.

Trend. Didalam penelitian tersebut menyebutkan bahwa forcast error terkecil yang diukur melalui nilai MSE. Selanjutnya metode ini digunakan ketika menunjukan adanya trend dan perilaku musiman .serta lebih cocok untuk membuat ramalan yang berfluktuatif atau mengalami gelombang pasang surut.

\section{Pengujian Kualitas Sistem}

Pengujian kualitas untuk mengetahui tingkat kualitas perangkat lunak aplikasi peramalan yang dihasilkan dalam penelitian ini. Pengujian kualitas sistem dilakukan untuk menguji tingkat kualitas perangkat lunak sistem yang dihasilkan berdasarkan empat karakteristik kualitas perangkat lunak di ISO 9126, yaitu functionality, reliability, usability, efficiency. 
ISO 9126 memiliki enam karakteristik namun hanya empat karakteristik saja yang dijadikan variabel dalam penelitian ini yaitu functionality, reliability, usability, efficiency. Dua karakteristik lainnya yaitu maintainability dan portability tidak menjadi fokus penelitian. metode yang digunakan dengan menggunakan kuesioner.

Responden dalam penelitian ini adalah produsen dan pedagang bordir Tasikmalaya yang berjualan di pasar tanah abang sebanyak 20 orang. Tanggapan responden dari pengujian ini adalah sebagai berikut

Tabel 2 Hasil Tanggapan responden berdasarkan aspek Funcionality

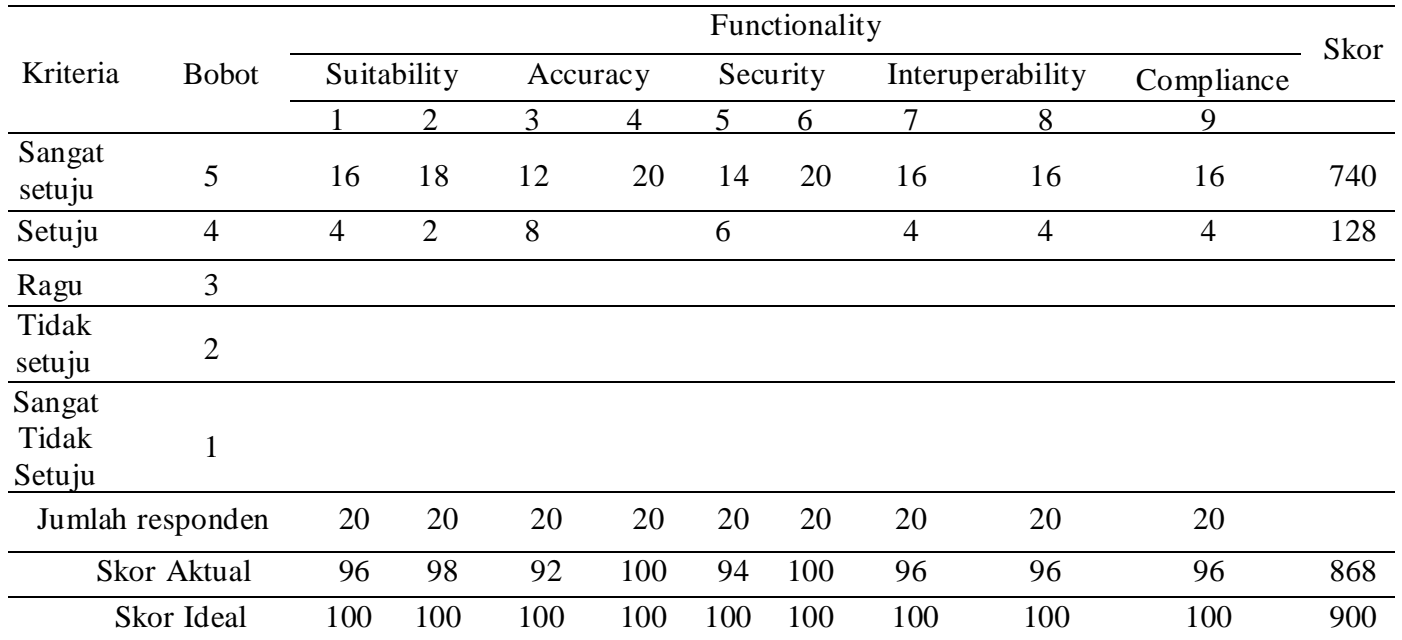

Hasil tanggapan dari responden untuk dikalikan dengan 100\% (868/900*100\%) dan aspek Functionality mayoritas sangat setuju berada dalam kriteria Sangat Baik, sehingga bahwa aplikasi peramalan ini memiliki berdasarkan tabel diatas dapat disimpulkan fungsionalitas yang sangat baik sesuai fungsi- bahwa tingkat functionality aplikasi peramalan ini fungsi yang dimilikinya. Persentase Skor dalam kriteria Sangat Baik dengan Presentase tanggapan responden sebesar $96,44 \%$ didapatkan sebesar $96,44 \%$. dari pembagian skor aktual dengan skor ideal lalu

Tabel 3 Hasil Tanggapan responden berdasarkan aspek Reliability

\begin{tabular}{|c|c|c|c|c|c|c|c|}
\hline \multirow{3}{*}{ Kriteria } & \multirow{3}{*}{ Bobot } & \multicolumn{5}{|c|}{ Reliability } & \multirow[t]{3}{*}{ Skor } \\
\hline & & \multicolumn{2}{|c|}{ Maturity } & \multicolumn{2}{|c|}{ Fault Tolerance } & \multirow{2}{*}{$\begin{array}{c}\text { Recoverability } \\
14\end{array}$} & \\
\hline & & 10 & 11 & 12 & 13 & & \\
\hline $\begin{array}{l}\text { Sangat } \\
\text { setuju }\end{array}$ & 5 & 14 & 16 & 12 & 20 & 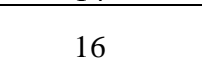 & 360 \\
\hline Setuju & 4 & 6 & 4 & 6 & & 4 & 80 \\
\hline Ragu & 3 & & & 2 & & & 6 \\
\hline $\begin{array}{l}\text { Tidak } \\
\text { setuju }\end{array}$ & 2 & & & & & & \\
\hline $\begin{array}{c}\text { Sangat } \\
\text { Tidak } \\
\text { Setuju } \\
\end{array}$ & 1 & & & & & & \\
\hline Jumlah res! & den & 20 & 20 & 20 & 20 & 20 & \\
\hline Skor A & & 94 & 96 & 90 & 100 & 96 & 476 \\
\hline Skor I & & 100 & 100 & 100 & 100 & 100 & 500 \\
\hline
\end{tabular}


Hasil tanggapan dari responden untuk aspek berada dalam kriteria Sangat Baik, sehingga Reliability memiliki Persentase Skor tanggapan berdasarkan tabel diatas dapat disimpulkan responden sebesar 95,20\% didapatkan dari bahwa tingkat Reliability aplikasi peramalan pembagian skor aktual dengan skor ideal lalu dalam kriteria Sangat Baik dengan Presentase dikalikan dengan $100 \%(476 / 500 * 100 \%)$ dan sebesar $95,20 \%$

Tabel 4 Hasil Tanggapan responden berdasarkan aspek Usability

\begin{tabular}{|c|c|c|c|c|c|c|c|c|c|c|}
\hline \multirow{3}{*}{ Kriteria } & \multirow{3}{*}{ Bobot } & \multicolumn{8}{|c|}{ Usability } & \multirow{3}{*}{ Total } \\
\hline & & \multicolumn{2}{|c|}{ Understandbility } & \multicolumn{2}{|c|}{ Learnability } & \multicolumn{2}{|c|}{ Operability } & \multicolumn{2}{|c|}{ Attractiveness } & \\
\hline & & 15 & 16 & 17 & 18 & 19 & 20 & 21 & 22 & \\
\hline $\begin{array}{l}\text { Sangat } \\
\text { setuju }\end{array}$ & 5 & 14 & 6 & & 20 & 12 & 20 & 16 & 20 & 540 \\
\hline Setuju & 4 & 6 & 10 & 20 & & 8 & & 2 & & 184 \\
\hline Ragu & 3 & & 4 & & & & & 2 & & 18 \\
\hline $\begin{array}{l}\text { Tidak } \\
\text { setuju }\end{array}$ & 2 & & & & & & & & & \\
\hline $\begin{array}{l}\text { Sangat } \\
\text { Tidak } \\
\text { Setuju }\end{array}$ & 1 & & & & & & & & & \\
\hline Jumlah res & den & 20 & 20 & 20 & 20 & 20 & 20 & 20 & 20 & \\
\hline Skor A & & 94 & 82 & 80 & 100 & 92 & 100 & 94 & 100 & 742 \\
\hline Skor I & & 100 & 100 & 100 & 100 & 100 & 100 & 100 & 100 & 800 \\
\hline
\end{tabular}

Hasil tanggapan dari responden untuk aspek Usability memiliki Persentase Skor tanggapan responden sebesar $92,75 \%$ didapatkan dari pembagian skor aktual dengan skor ideal lalu dikalikan dengan $100 \%(742 / 800 * 100 \%)$ dan berada dalam kriteria Sangat Baik.

Tabel 5 Hasil Tanggapan responden berdasarkan aspek

\section{Eficiency}

\begin{tabular}{|c|c|c|c|c|c|}
\hline \multirow{3}{*}{ Kriteria } & \multirow{3}{*}{ Bobot } & \multicolumn{3}{|c|}{ Efficiency } & \multirow{3}{*}{ Total } \\
\hline & & \multicolumn{2}{|c|}{$\begin{array}{l}\text { Time } \\
\text { behaviour }\end{array}$} & \multirow{2}{*}{$\begin{array}{l}\text { Resource } \\
\text { Unlisation } \\
25 \\
\end{array}$} & \\
\hline & & 23 & 24 & & \\
\hline $\begin{array}{l}\text { Sangat } \\
\text { setuju }\end{array}$ & 5 & 20 & 16 & 20 & 280 \\
\hline Setuju & 4 & & 4 & & 16 \\
\hline Ragu & 3 & & & & \\
\hline $\begin{array}{l}\text { Tidak } \\
\text { setuju }\end{array}$ & 2 & & & & \\
\hline $\begin{array}{c}\text { Sangat } \\
\text { Tidak } \\
\text { Setuju }\end{array}$ & 1 & & & & \\
\hline Jumlah res & den & 20 & 20 & 20 & \\
\hline Skor A & & 100 & 96 & 100 & 296 \\
\hline Skor I & & 100 & 100 & 100 & 300 \\
\hline
\end{tabular}

Hasil tanggapan dari responden untuk aspek efficiency memiliki Persentase Skor tanggapan responden sebesar $98,67 \%$ didapatkan dari pembagian skor aktual dengan skor ideal lalu dikalikan dengan 100\% (296/300*100\%) dan berada dalam kriteria Sangat Baik.

Berdasarkan perhitungan data yang diperoleh dari kuesioner, maka berikut rekapitulasi hasil pengujian kualitas berdasarkan empat aspek kualitas perangkat lunak menurut ISO 9126.

Tabel 6 Hasil pengujian kualitas ISO 9126

\begin{tabular}{ccccc}
\hline Aspek & $\begin{array}{c}\text { Skor } \\
\text { Aktual }\end{array}$ & $\begin{array}{c}\text { Skor } \\
\text { Ideal }\end{array}$ & $\begin{array}{c}\text { \% Skor } \\
\text { Aktual }\end{array}$ & Kriteria \\
\hline Functionality & 868 & 900 & $96,44 \%$ & Sangat Baik \\
\hline Reliability & 476 & 500 & $95,20 \%$ & Sangat Baik \\
\hline Usability & 742 & 800 & $92,75 \%$ & Sangat Baik \\
\hline Efficiency & 296 & 300 & $98,67 \%$ & Sangat Baik \\
\hline Total & 2382 & 2500 & $95,76 \%$ & Sangat Baik \\
\hline Berdasarkan & tabel & diatas & dapat
\end{tabular}

disimpulkan bahwa tingkat kualitas perangkat 
lunak aplikasi peramalan secara keseluruhan memiliki Skor Aktual sebesar 2382 dan Skor Ideal sebesar 2500 serta memiliki presentase sebesar 95,76\% dengan kriteria Sangat Baik. Aspek kualitas tertinggi berada pada aspek Efficiency dengan presentase sebesar 98,67\%, selanjutnya Aspek tertinggi urutan kedua berada pada aspek Functionality dengan presentase 96,44\%, Aspek urutan ketiga berada pada aspek Reliability dengan presentase sebesar 95,20\% dan aspek terendah berada pada aspek Usability dengan presentase sebesar $92,75 \%$.

\section{PENUTUP}

Aplikasi peramalan ini dapat membantu para pedagang bordir Tasikmalaya dalam meramalkan penjualan berikutnya. Berdasarkan hasil pengujian kualitas perangkat lunak menggunakan ISO 9126 dalam penelitian ini dibuktikan bahwa kualitas perangkat lunak sistem peramalan yang dihasilkan dengan empat kriteria aspek ISO 9126 yaitu aspek Functionality, Reliability, Usability, dan Efficiency maka dapat disimpulkan bahwa hasil pengujian Sangat Baik dengan presentase $95,76 \%$ sehingga perangkat lunak ini sangat layak untuk diimplementasikan. Aplikasi peramalan ini sangat baik digunakan dan sangat bermanfaat bagi para pedagang agar pendapatan mereka menjadi optimal dan biaya produksi menjadi lebih efisien.

\section{UCAPAN TERIMA KASIH}

Apresiasi dan terima kasih kepada Direktorat Riset dan Pengabdian Masyarakat, Dirjen Penguatan Riset dan Pengembangan, Kementerian Riset, Teknologi dan Pendidikan Tinggi yang telah membiayai kegiatan penelitian kompetitif nasional Penelitian Produk Terapan (PPT) Tahun 2017 dengan judul: "Peramalan penentuan jumlah permintaan konsumen berbasis teknologi informasi terhadap produk bordir pada kota Tasikmalaya". Terima kasih juga kepada Kopertis Wilayah III Jakarta dan Lembaga Penelitian dan Pengabdian Masyarakat Universitas Indraprasta PGRI yang telah membantu kegiatan penelitian ini melalui Kontrak Penelitian 0428/K3/KM/2017, Tanggal 24 Mei 2017. Dan Surat Perjanjian/Kontrak Penelitian UNINDRA Nomor: 0544/SKP.LT/LPPM/UNINDRA/VI/2017,

Tanggal 05 Juni 2017.

\section{DAFTAR PUSTAKA}

Andini, T. D., \& Auristandi, P. (2016). Peramalan Jumlah Stok Alat Tulis Kantor di UD Achmad Jaya Menggunakan Metode Double Exponential Smoothing. Jurnal Ilmiah Teknologi Informasi Asia, 10(1), 1-10.

Assauri, S. (2016). Manajemen Operasi Produksi (3rd ed.). Jakarta: PT Raja Grafindo Persada.

Chuong, W. J. S. \& S. C. (2014). Operations Management; An Asian Prespective. Jakarta: Salemba Empat.

Kristien Margi S., S. P. W. (2015). MEtode Single Exponential Smoothing Untuk Prediksi Penjualan Pada Periode Tertentu (Studi Kasus : PT. Media Cemara Kreasi) 1. Analisa Dan Penerapanmetode Single Exponential Smoothing Untuk Prediksi Penjualan Pada Periode Tertentu (Studi Kasus: PT. Media Cemara Kreasi), (1998), 259-266.

Pramita, W., \& Tanuwijaya, H. (2010). Penerapan Metode Exponential Smoothing Winter Dalam Sistem Informasi Pengendalian Persediaan Produk Dan Bahan Baku Sebuah Cafe. Seminar Nasional Informatika, 2010(semnasIF), 219-225.

Pressman, R. S. (2010). Software Engeneering A Practitioner Approach (7th Editio). New York.

Rachmat, A. (2010). Algoritma dan Pemrograman 
dengan Bahasa C - Konsep, Teori, \& Victor, R., Andreas, Y., Prof, J., Suria, D., \& No, S. Implementasi. Yogyakarta: Andi Offset.

Render, J. H. \& B. (2015). Manajemen Operasi (11th ed.). Jakarta: Salemba Empat.

Sabilla, C. T. (2014). Latar Belakang, (2009), 1-8. https://doi.org/10.1017/CBO9781107415324.0 04 (2012). Aplikasi Peramalan Stok Barang Menggunakan Metode Double Exponential Smoothing. Jurnal Sistem Informasi, Vol 7, No 2, September 2012 : 123 -141, 2, 123-141. 